\title{
Exploratory Study Of The Relationship Between Poverty And Crimes In Albany/Dougherty, Georgia
}

Amaechi N. Nwaokoro, Albany State University, USA Clifford Marshall, Albany State University, USA

Shiwam Mittal, Birla Institute of Technology and Sciences, Pilani, India

\begin{abstract}
Both the crime and poverty rates in Albany/Dougherty County, Georgia, are substantially high. Therefore, the objective of this study is to highlight the sources of the relationships between poverty and crimes in this area. The paper makes additional contributions by exploring the impact of non-market factors of segregation and discrimination on poverty in the remote Dougherty County that is also characterized by both dualistic and restricted environments. The crimes seem to be driven by poverty that is characterized by other factors - the remoteness of the county, exit of some big establishments, declining urban education, increasing unemployment rate, non-harmonized economic environments, and by the presence of teenage pregnancy. These prevailing adversities have cumulatively suppressed the real average weekly wage rate, proxy of poverty. Crimes and poverty control measures are included in the study.
\end{abstract}

Keywords: Crimes; Poverty; White Migration; Restricted Economy; Segregated Economies; Dualistic Economy; Disproportional Incarceration; Purchasing Power

\section{INTRODUCTION}

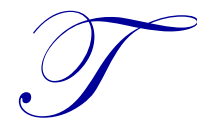

here are huge levels of poverty, economic disparity, unemployment, crimes, and incarceration in the rural and agricultural city of Albany and Dougherty County, Georgia. In this county, Blacks, White, and Hispanics, respectively, make up $60.1 \%, 37.34 \%$, and $1.3 \%$ of the county's 2010 population estimate of $96,065^{1}$. A few corporate establishments provide most of the employment opportunities in the Albany $\mathrm{MSA}^{2}$. The city of Albany is ranked fourth among the nation's poorest cities ${ }^{3}$. This national poverty exposure may not only relate to low educational achievements from the area's public schools, but also may be linked to some social issues. Also, the prevailing conditions of segregation, institutional discrimination, and restricted opportunities, especially in restricted environments, could be capable of inducing criminal behavior. The level of poverty in the county may relate to the intensity and extensive nature of some of the high order crimes.

Becker (1968) focused entirely on financial motives for explaining crimes. This explanation seems to be a generalized motive for addressing crimes. Since Becker's paper was published, various authors have introduced some other dimensions for explaining poverty and crimes. Particularly, Ehrilch (1973) introduced a crime agent who shares time on criminal activity, on legitimate activities, and on leisure. This particular agent that understands the associated probability of an arrest operates in a criminal activity as if he is operating in legitimate labor market activities. Income from criminal activities may be interpreted as income from legitimate labor market activity. The crime rate here is expressed as being positively related to income inequality and is inversely related to arrest quotient and expansionary economy (Chiu and Madden, 1998).

\footnotetext{
${ }^{1}$ The estimates are retrieved from: http://www.city-data.com/county/Dougherty County-GA.html; http://doughertycounty.georgia.gov/03/home/0,2230,8466851,00.htm1

${ }^{2}$ The largest establishments are retrieved from:

http://explorer.dol.state.ga.us/mis/historical/qcew/top employers/top10/albany09q1.pdf

${ }^{3}$ The estimate is retrieved from: http://doughertycounty.georgia.gov/03/home/0,2230,8466851,00.html
} 
Donohue, III and Levitt (2001) attributed declining fertility in the 1990s to legalized abortion mandated in 1973 to explain the tremendous decline in both homicide and property crimes. With other things being constant, a declined fertility would lead to an increase in family per capital income that would create fewer propensities for engaging in criminal activities. Also, Donohue and Levitt (2004) found an inverse relationship between abortion and crimes. Other authors introduced some other demographic factors - low education for single mothers, procreation of teenage mothers, and increasing presence of single mothers (Glaeser and Sacerdote, 1999). Particularly, Dagg (1991) presents that the sons from out of wedlock families have substantial probabilities of participating in crimes.

From aggregate data, Hartung \& Pessoa $(2007)^{4}$ use demographic factors of the offsprings of single mothers and teenage fertility to predict the propensity of participating in criminal ventures. The demographics were able to show propensity to participate in both property and violent crimes. It is clear that demographic dimensions could explain poverty and therefore propensity to committing crimes. A vicious circle of poverty exists in the restricted African American community of Dougherty County. Persistent poverty could be the basis for the high level of criminal activities in the county, as explained in Kelly (2000) and Nwaokoro (2012).

Dougherty County encompasses the various factors as identified by the cited authors and some other critical factors. Restrictive and dualistic environments and social conditions of segregation and institutional discrimination characterize the county. Within the county, both the east and south-side have high distribution of Black population. The White population distribution is mostly in the west and north. These adverse conditions would therefore diminish the functionality of economic markets and the realization of economies of scale. The outcome of this market-failed situation would breed hopelessness and propensity for an engagement in criminal activities (Peeples and Loeber, 1994).

Both the east and south sides suffer from economic retardation as a result of a non-harmonized economic development in the county. Most of the scattered, small-scale businesses in these areas are owned by subcontinental Indians, Whites, and Koreans. The west-side contrasts the east and south by having some robust economic development. Poverty and crime, therefore, would be expected as outgrowth from a restricted environment that experiences both market and policy failure.

Urbanization leads to both White and Black middle class flight, especially from the city of Albany. This migration drains innovators and economic resources out of Albany and the county, thereby promoting poverty that seems to explain crimes. The continuous migration has led to lots of vacant buildings and decaying structures and infrastructures that are common, especially in the downtown area of Albany. As the county's economy declines due to the migration, the neighboring counties experience increase in both their population and economies. The entrepreneurs who migrated to the neighboring counties and who still own businesses in the Dougherty County, would earn revenue that would end up having an expansionary impact on the economies of the counties migrated to. A declining Dougherty County economy would therefore create poverty that would lead to incentives for criminal rationalization and activities.

Another situational social factor that breeds poverty and crime is a non-diversified public school system and the colleges in the county. Since the majority of the colleges attract students mostly from the African American population, the related expenditures, revenues, and incomes from the non-diversified environment would not be sufficient to bubble up the economic development of the county. Segregated environments would experience economic stagnation, the impact of hedonic activities, and lack of strength in diversity. People are trapped in the restricted and segregated cultural environments that face a high severity of resource scarcity. Consequences from the restricted environments with a severe resource scarcity are likely to be poverty and crime. A low public school academic achievement would compel poverty that some individuals could address by self-selecting criminal activities.

${ }^{4}$ http://www.abep.nepo.unicamp.br/Seminariohttp://www.abep.nepo.unicamp.br/SeminarioPopulacaoProbrezaDesigualdade2007/ docs/SemPopPob07_1062.pdf

278 Copyright by author(s) Creative Commons License CC-BY

2013 The Clute Institute 
The remoteness of the county, along with the exodus involving both White and middle-class Black, and big businesses in the restricted and dualistic environments have led to a high unemployment rate in the county. Given long driving hours from the county to the nearest industrial cities of Atlanta, Georgia, and Tallahassee, Florida, the unemployed may not seek economic opportunities in these cities and could turn to crimes to maximize income. The real average weekly wage appears to be very low in the face of a high unemployment rate. Generally, a low wage rate emanates from a declining demand for labor, specifically from having minorities highly distributed in low paying jobs or paying low wage rates to the members of the minority, on comparable jobs that pay higher wage rates to the members of the majority. Crimes could characterize restrictive environments with market failure. In this situation, people are likely to spend their productive time in hedonic and criminal activities. The presence of some opportunities for growth may not be attractive if there is a strong self-selection in a restricted environment for immediate consumption gratification. When some people in this culture engage in crimes, they could be relating to only events - poverty and crimes that they have known for years.

Incarceration is on a big scale and its' associated rate is higher than the incarceration rate at the state level. The incarcerated are mostly young and uneducated. More males than females are incarcerated. Heavy incarceration of males appears to highlight the male as the traditional bread winners who would most likely self-select criminal activities to attract some economic security. Bearing on this conventional role, the male is more likely to have higher frequency in repeating crimes than would the female. The African American male group is disproportionally incarcerated. This disproportional incarceration could reflect discrimination of this group by the criminal justice system and a high severity of economic deprivation faced by the group. These misery conditions, along with the conditions posed by teenage pregnancy and unwed mothers, get in the way of the market functionality to lead to persistent poverty and high level of crimes. Given these market distortions, a solution to poverty in the county may require a robust amount of exogenous investments that could lower the unemployment, incarceration, poverty, and crimes.

The objective of this study, therefore, is to highlight the sources of relationships between poverty and crimes in Dougherty County. Particularly the paper makes contribution by exploring the impact of segregation and discrimination that give rise to dualistic, restricted, and impoverished environments that have impact on poverty and crimes. From the dualistic environments, crimes seem to be driven by poverty that is characterized by factors of the remoteness of the county, declining urban education, and the presence of a rising unemployment rate. This research also relates to the poverty discussion in Owen \& Martinez (2008), Hoynes (2006), Theodos, and Bednarzik (2006), D'Amico and Maxwell (1994), and Smith and Vavrichek (1987).

\section{Relating Poverty to Crimes}

This section explores the issues that link poverty to crimes in the county's restrictive and dualistic environments. The county appears to be high poverty and crime environment. In $2008,25.3 \%$ of the county's residents were below the poverty income level. This estimate is higher than the respective estimate (14.7\%) at the state of Georgia's level and the county's 2000 poverty rate of $24.8 \%$ declined slightly to $22.3 \%$ in 2010 (Georgia County Guide, 2010) ${ }^{5}$. In turn, poverty seems to reflect the county's unemployment rate that increased from $6.9 \%$ in 2008 to $10.2 \%$ in 2009 (Georgia Department of Labor website, 2010). An increasing unemployment rate would explain a severity of income resource scarcity that could, in turn, create incentives for participating in crimes.

Education as an income equalizer is usually cited as a pathway out of poverty and crimes. An unacceptable standard of educational achievement in the segregated city of Albany/Dougherty County ${ }^{6}$ public schools system compels poverty that some individuals could address by self-selecting criminal activities. Therefore, an environment with a limited education could be a breeding ground for crimes arising due to poverty. A sub-standard education imparts on market skills, productivity, and the associated market compensation (Browne, 1997; Theodos and Bednarzik, 2006, p.43). A low education will retard efficiency in production and create dependency on a few rich people for the provision of economic opportunities. Also, a high distribution of uneducated people will create problems with irrational use of scarce resources, inability to conduct marginal analysis, and comprehend the

${ }^{5}$ http://poverty.suite101.com/article.cfm/poverty in Georgia

${ }^{6}$ Dougherty County School System provided the respective graduation and dropout rates estimates of $57.44 \%$ and $6.39 \%$. 
consequences of criminal actions. Where the consequences of an action are not clearly understood due to lack of sufficient education, an incentive for engaging in crimes could be rationalized.

East Albany is particularly characterized by a low level of educational achievement ${ }^{7}$. D'Amico and Maxwell (1994), Theodos \& Bednarzik (2006), and Gardner \& Hern (1992) emphasized the relevance of education for equalizing demographic wages and for diminishing market-based discrimination. Browne (1997) associated a low level of education with a high proportion of Black women than White women as family heads. With a positive relationship between education and human capital, neighborhoods that are characterized by low levels of education will experience a non-vertical market learning curve, low efficiency and innovation, and a low entrepreneurship. Inadequate human capital in the East Albany area leads to people of other ethnic groups, who are not usually members of the community, to actively control the commerce in this community. These consequences from insufficient level of education will lead to low productivity and retarded opportunities for personal and collective development. An environment that is characterized by non-market activities is prone to criminal ventures. Also, hedonic activities could replace market activities. Poverty in this environment could compel criminal activities, as explained by monetary incentives for engaging in criminality (Becker, 1968).

Withdrawal of big businesses from the county elevates poverty. Big businesses, including Firestone, the US Naval Air Station, and Merck Pharmaceuticals, have withdrawn from the county. Rising economies of the neighboring counties seem to be attracting small businesses from the Albany/Dougherty area. Schmitt (2004) describes a situation that experiences an exit of businesses as a de-trending job opportunity area. Diminishing job opportunities could compel criminal activities in order to provide oneself with some income in the absence of market-based incomes.

Also, Caucasians and the middle-income Africans Americans have been migrating out of the county since the 1970s. The movement seems to reflect increasing city vices, low student academic achievements ${ }^{8}$, and a need for a superior suburban education. This kind of education is sought after for creating excellent human capital that gives a rise to excellent earning opportunities in the labor market (D’Amico and Maxwell, 1994; Gittleman \& Wolff, 2004). Both the exit of businesses and the overall migration depopulate and depress the economy of the county and lead to economic deprivation of the poor and working poor, especially in the city of Albany that became a predominantly African American city between 1980 and 2000. Between 2000 and 2010, the city of Albany's population declined by $0.64 \%$ and relative to the overall change in the population, the White population declined by 7.80\%, while that of African American increased by 7.28\% (Adams-Cooper, 2011; Farr \& Slade, 2008) ${ }^{9}$. Given the depopulation, a contrasting economy, low wage compensation, and an inability to attract professionals to the county to create economic opportunities, the poor may have the propensity to self-select hedonic and criminal activities.

Relative to the discussion in Davis \& Balazs (2011), the county is remotely located from the nearest industrial cities of Atlanta, Georgia, and Tallahassee, Florida. The remoteness prevents labor, opportunities and other economic resources from being mobile geographically and among jobs. This remote condition perpetuates poverty that could explain the extensiveness of the crimes. Farr \& Slade (2008) explain that poverty has compounded since the paving of Georgia's part of Interstate 75 that runs east of Albany. Since the construction, new development has taken place along the highway.

Dualistic environments in the county do not attract uniform macroeconomic development. Economic development takes place mostly in the west and north sides where the White population resides. Generally, the eastside is dotted with very few retailing and service-oriented businesses and with many faith-based organizations. Economic development policy may need to consider that the poor have a higher marginal propensity to consume (MPC) than do the rich, as expressed in Ballard (2008) in order to achieve some appreciable uniform level of economic development in the county. Since the poor spend more out of every dollar received than do the rich, the firms making the goods and services that the poor buy regularly may need to be sited in an impoverished environment. Since the county's economy is not inclusive, the task of resolving both poverty and inequality and

\footnotetext{
${ }^{7}$ In this area, $40.0 \%$ of the adults lack high school diplomas and only $5.8 \%$ of them has college degrees (Farr \& Slade, 2008).

${ }^{8}$ These indexes are accessible at: http://services.georgia.gov/gbi/crimestats/viewCrimeStatReport.do

${ }^{9} \mathrm{http}: / /$ Censusviewer.com/city/Albany
} 
crimes becomes very hard for the market to take on; hence, there are perpetual poverty and extensiveness of crimes. An extensive inequality is evidenced by the fact that the average African American's purchasing power is roughly fifty-five cents for every one dollar of the average White person's purchasing power ${ }^{10}$ (Baldwin and Johnson, 1996). This unacceptable level of inequality would be a source of poverty that could trigger criminal activities and comparative disadvantage in the economy (Bagi, 2008).

Teenage pregnancy seems to be another source of poverty in the county. Whereas the teenage mother and her baby become dependents of the teenage mother's parents, the per capital income of the family will decrease drastically. The poverty arising from the increased membership of this type of family is capable of instigating the teenage mother or the offspring, or both, to engage in crimes. Unless the teenage mother is highly motivated, getting the basic education and raising children that would understand the societal conventions that could diminish crimes may be an up-hill battle. In this situation, having education and having children could be close substitutes. An intergenerational vicious circle of poverty and crimes could take place where the preference for fertility dominates in the substitution. Crime is likely to be in a family that has an absence of a father who is needed for controlling the code of conduct of the kids. Comanor \& Phillips (2002) find the absence of fathers in families to be the most important factor describing child delinquency. Young single families are most likely to have both emotional and economic deprivations, and with these deprivations, teenage mothers could generate some costs to the state. Beside the societal cost of crimes, the state could incur costs for the welfare of the babies of teenage mothers, and also for providing training and skills to the teenage mothers.

Political equity seems to override economic equality, and this situation leads to poverty due to limited economic entrepreneurship and with marginal growth from the government sector (Farr \& Slade, 2008). People usually discuss politics and historical issues at all levels. Politics is sought after for expanding awareness and political and civil rights. Much focus on politics comes from the understanding that the struggle for the realization of human rights that are supposed to be guaranteed by common or conventional laws, emanated from political activities. Involvement in political activities would compare to the involvement in faith-based activities. The general understanding is that politics and faith-based activities played a significant role for the realization of African Americans' human rights. Politics particularly seem to provide a quicker evidence of a sense of citizenry than do the economic opportunity and entrepreneurship. Participation in politics seems to provide African Americans with some level of equity that is hard to come by in a competitive free market arena where those who could understand the market norms earn competitive return.

Participating in politics to advance personal and collective economic welfare would require the ability to articulate and is not usually capital intensive. It is unlike the economic arena where businesses require some reasonable amount of capitalization to be competitive. Unlike the business arena, it does not take long to reap the benefit from politics if one is successful. Some businesses may not go beyond their short run periods due to persistence of the fixed production costs. For these reasons, people gravitate to politics and would seem to forget the economic arena where much more economic reward (profit) can be realized for lifetime utility maximization.

In politics, it is relatively easier to draw supporters than to draw customers to start up a business. People who could articulate their point could win elections and if they lose, the personal losses may not be so much as it would be in business. In business, short-run losses could inhibit some potential business ventures. Given the myopic advantages associated with politics, people in a restrictive environment would seem to prefer ventures in politics just as they prefer faith-based activities. Preference for politics for self-vindicating and emancipating from poverty leads to oversight on the need to focus on profit maximization from neighborhood business creation. In the African American neighborhood of East Albany, this non-market political preference leads members of other ethnic groups that may not live in the neighborhood to have a comparative advantage in the economic activities in this neighborhood. The revenues generated may not be spent in this neighborhood of operation for more economic opportunity.

\footnotetext{
${ }^{10}$ This empirical information comes from the purchasing power data of The University of Georgia, Terry College of Business, Selig Center for Economic Growth.
} 
Success in politics tends to promote faster individual reputation and recognition than does business. Generally, people do not seem to associate their economic welfare with entrepreneurial activities as they associate their welfare with politics because getting the benefits from entrepreneurial activities, unlike in politics, could take place in the long run. With this understanding, the citizenry's hope and aspiration seem to be placed on politicians than on the business people. Like pastors, politicians are seen as those who discuss and shape the contemporary events that affect the lives of ordinary people. Therefore, people could credit or discredit politicians regarding the direction of the common price level; for example, that which describes the real money of the citizens. They tend to entrust their general welfare and financial security to politicians that are accessible to them, given that business entrepreneurship is not common, especially in the restricted areas of the county.

The understanding is that politics relate to public goods that the citizens use on a daily basis, whereas the business arena comprises of a few participants whose primary goal is strictly to maximize profit without regard to a general welfare. So interaction to alleviate poverty and crime is usually handled by nonprofit organizations and the Chamber of Commerce. Residents tend to feel that businesses will only engage their respective markets only for the sake of maximizing profit and would not return some values to the community unless they are compelled. They tend to feel that politicians could prevent exits of businesses from their community. So, instead of withdrawing from the community, the residents would want the businesses to engage the community with discussion on how to prevent business exits in order to alleviate poverty. A focus on politics, as characterized here, would perpetuate poverty and crimes in the absence of strong business entrepreneurial activities in the county.

Poverty and the number of convicted criminals are - by race and ethnicity - disproportionately distributed. U.S. Bureau of the Census (2000) characterizes this assertion from the following paragraph on poverty and race/ethnicity in Dougherty County ${ }^{11}$. Adjusted to 2005 dollars, Dougherty County has a medium-low household income of about $\$ 36,193$. This amount is just about 37.2 and $35.8 \%$, respectively, below the median incomes in the state of Georgia and of the US. There has been a growth of median household income since the year 2000 and the growth benefited the Asian Race/Ethnicity mostly. This group had the median household income increased by $367 \%$ in the period of 2000 to 2005 . An ability to maximize income from the economic markets by this group could explain the low proportion of the members of the group that is incarcerated ${ }^{12}$. An understanding of profit reward from foresight in economic markets would mostly explain the economic performance of the group. Since the year 2000 , the poverty rate in the county has declined from $24.8 \%$ to $20.0 \%$. Inflation adjusted household income experience $9.9 \%$ growth from 2000's value. Given this growth, Dougherty County is described as one out of four counties in the percent of growth of household income at the state of Georgia level.

This paragraph is also based on the characterization of race and ethnicity and income from the U.S. Bureau of the Census (2000). American Indian and Alaska Native groups had a median household income of $\$ 30,180$ which is $16.6 \%$ less than the median income of all the county's households. White residents of Dougherty County had a median income of $\$ 47,451$ adjusted to 2005 dollars. This amount has increased by $31.1 \%$ over the respective 2000 median income. Asian groups had household median income of $\$ 42,830$, and this amount is by $18.3 \%$ higher than the median household income of the entire county's households. Hispanic households recorded a median income of $\$ 55,231$, which is by $52.6 \%$ greater than the median income of all households. Black or African American had a median household income of $\$ 27,635$ which is $23.6 \%$ lower than that of all households. Relative to other counties and areas throughout the U.S., Dougherty County is a high poverty area and has a poverty rate of $24.8 \%$ reflective of families whose income is below the 1999 poverty level. By 2000, American Indian and Alaskan Natives had the highest poverty rate $(34.8 \%)$ in the county. The children whose ages range from 6-11 had the highest demographic poverty rate $(39.8 \%)$ in the county.

These explanatory and descriptive statistics reflect the distribution of race and ethnic population of the incarcerated groups in Dougherty County. There is disproportional incarceration from the groups with low median household incomes. Black or African American had the lowest household median income and are disproportionally incarcerated. For every one White person, about six African Americans are incarcerated. The low proportion of the

\footnotetext{
${ }^{11}$ The statistics in this paragraph and in the following paragraph are retrieved from: http://www.ecanned.com/GA/Dougherty County.shtm1.

${ }^{12}$ See Georgia Department of Corrections website for the understanding of the number of the incarcerated members of this group. 
incarcerated White shows that the group understands resource scarcity, opportunity costs, marginal analysis, and the functionality of the economic markets. These attributes provide a high return of household median income and low levels of poverty, and of the proportion incarcerated.

\section{Limitedness of Economies of Scale in Business}

Generally, most family businesses in the county do not get to the performance level to explore and utilize economies of size. Limited market, dualistic, and restrictive nature of the county tend to inhibit business performance level from achieving a substantial level of size. In 2006, the average establishment hired roughly seventeen employees ${ }^{13}$. Some businesses usually employ mom and dad first and then immediate family members. A few highly established businesses, such as Wal-Mart, Target, and K-Mart, tend to dominate the county's economy ${ }^{14}$. These businesses seem to be able to pass low prices onto their customers and to make a high level of employment due to their sizes. Wal-Mart, in particular, has spread operation to East Albany and is covering some market niches that were traditionally covered by specialized small businesses. Wal-Mart has ventured into a gasoline filling station, banking, eye glasses, photography, hair care, pharmacy, and restaurant businesses. Small businesses may have cut operations or closed entirely as a result. The outcome of involuntary business closures would relate to involuntary displacement of jobs, pride of ownership, and profit incentive, and may have imparted on poverty and property crimes.

Specifically, the highly limited sizes of operations of the few businesses owned by African Americans in the county tend to inhibit the competitiveness of the businesses against the related White businesses. Firms with employment size ranging from one to four employees employ roughly $46 \%$ of all the total employees in the county ${ }^{15}$. This situation leads to the imbalanced economic development between the various regions of the county. The Whites' favorable comparative advantage in the county stems from lack of enough African American entrepreneurship and business knowledge and their apparent preference for public and nonprofit activities. With these shortcomings and limited expected volume purchases, African American businesses are likely to have a high average cost of production that would put the businesses on comparative disadvantage footing. The price charged has to be high enough to cover the average cost of production that may relate to a high-fixed cost or overhead. With severe competition in the presence of a high average cost of production, the opportunity cost of doing business would be very high. From this situation, the respective small business owners could choose to return to their reservation opportunities (reservation wages). These strategic business distortions are capable of diminishing minority business enterprise and could promote preference for crimes to maximizing short-run monetary benefits.

\section{Nature of Crimes}

Crimes in the country can be classified as property and violent crimes. All the crimes include murder, rape, robbery, assault, burglary, larceny, and vehicle theft. Generally, property crimes - robbery, burglary, larceny, and vehicle theft - are tied to monetary incentives and they account for the majority of all the crimes. Murder could be considered property or violent. Becker's monetary incentive to explaining crimes seems applicable those in Dougherty County.

Scarcity of income (deprivation) would hold strongly in the explanation for committing property crimes. People's commission of property crimes would depend on their crime resistance level and the severity of the resource constraint. Property crimes are more likely to be committed, whereas individuals use crimes to punish the society for tolerating a high level of resource scarcity that leads to societal poverty. In this situation, the intensity and extensiveness of crimes committed would increase as scarcity becomes more severe during a recession. An extreme situation of severity and resource scarcity could lead to criminals substituting market-based incomes with crime-based incomes.

\footnotetext{
${ }^{13}$ See page 223 of 2008 \& 2009 Georgia Statistical Abstract published by Terry College of Business.

${ }^{14} \mathrm{Http}: / /$ explorer.dol.state.ga.us/historical/qcew/top employers/top10/albany09q1.pdf

${ }^{15}$ See page 223 of 2008 \& 2009 Georgia Statistical Abstract published by Terry College of Business.
} 
Violent crimes - rape, assault, and murder - may not necessarily reflect monetary incentives. They could take place for several reasons not addressed by Becker's monetary incentive for explaining crimes. Violent crimes could arise due to insincerity of spouses that may not relate to monetary values. A disagreement arising from a misplacement of a TV remote control could lead to a murder crime that may not have monetary implications. In this case, disagreement leading to the murder is coming from an inability to have instant access to hedonic TV pleasure. Violent crimes can be common, especially in a restrictive environment where hedonic activities dominate. Also, the need for hedonic activities could lead to rape. Using illegal drugs (hedonic activity) to generate utility can cause more than the associated crime to causing some violent crimes that may not be related to monetary incentives.

Some domestic violent crimes may not have monetary implications. Over-excitement from alcoholic (hedonic influence) can lead to violent crimes that may not be addressed by monetary values. Hedonic activities are likely to characterize a restricted environment, like East Albany, where some of the market indexes and the level of educational achievement are not favorable to the community. These activities could lead to violent crimes. Police shootings and killings due to prejudice and racial discrimination will be violent crimes that are not explained by monetary incentives.

\section{Characteristics of Criminals}

Convicted criminals in Dougherty County are mostly males. The majority of the criminals in every ethnic group incarcerated are males. This male majority status would imply that the males are most likely to engage in criminal activities to attract economic reward for their families. Males will take sufficient risks to draw economic security from criminal activities. Providing economic security for the family rests on the conventional notion that the male is the defender of the family's general security, particularly economic. From this perspective, the male will engage in crimes, even if they are not professed in mind. Bearing on the traditional role in the family, the male could self-select criminal activities due to loss of market incomes. The frequency of selecting criminal activities is likely to increase in a situation whereby the male, as the major breadwinner, experiences a continuous loss of market income.

Bearing on the male's conventional role, he is more likely to have higher frequency in repeating crimes than would the female. Due to the traditional role that the male is expected to 'hold in' the family, a previous conviction record tends to haunt him more than it would haunt the female. Society is most likely to sympathize more with female felons than with male felons when providing them with market-related opportunities that could prevent a repeat of crimes. The male felons that may not earn enough of this sympathy to attract economic opportunities may want to maximize economic welfare by advancing the propensity to commit more crimes.

By ethnicity, the African American male group is disproportionally incarcerated. If economic deprivation explains crimes, this disproportional incarceration would highlight this group as the most economically discriminated that therefore suffers more than other groups from the economic deprivations. The discrimination may have imparted on the criminal justice system that led to the disproportional incarceration. Along with economic discrimination, inadequate educational preparation and inability to understand the free enterprise system may lead to highly limited African American entrepreneurship and business partnership. These adversities may have imparted heavily on the African American males to explain the group's economic deprivations, lack of access to criminal justice system, and less resistance to committing crimes. These challenges are likely to be the basis for disproportional incarceration.

The age distribution of the incarcerated is not recorded at the county level. At the State of Georgia level in 2010, the incarcerated are mostly at their productive ages that range from 1 to 39 years, with $71 \%$ of all the incarcerated being in their teens, twenties, and thirties (Georgia Department of Corrections, 2010). This macro empirical information would reflect the age distributions of the incarcerated at the county levels. Incarceration will diminish productive human endowment that could have been signaled in an economic market. Where the incarcerated period tends toward infinity, the incarcerated will lose the entire respective endowment and generate some costs to the society. The felons and incarcerated in this disproportionally incarcerated age group are most likely to have a high severity of resource scarcity and low economic opportunities. This assertion would give support to Becker's evaluation of crimes with resource scarcity. 
A low educational attainment, especially the vulnerable younger members of the population, could lower the moral understanding of private ownership acquired out of economic markets. Whereas a low level of education applies, a would-be-incarcerated is likely to exercise ownership of owned property by engaging in criminal activity. Recognition of resource scarcity would tend to be illusive where illiteracy prevails. Where this situation applies, saving out of income to acquire capital for entrepreneurial activity becomes hard to articulate. Without resource scarcity recognition, the benefit of conducting marginal analysis to maximize economic benefits in an economic arena may be lacking. The benefit maximized in the absence of adequate and relevant educational preparation is unlikely to relate to economic activity where marginal benefit is equal to marginal cost. A situation of an extreme low market reward due to limited education can lead to poverty that could compel criminal activities. Limited education would reduce visualization of the importance of the necessary trade-offs and opportunity costs expressions in a free enterprise economy. Improper expression of these market concepts can emanate from a limited understanding of the basic principles of a market-driven economy.

\section{Expected Benefits from Crimes}

Scarcity of resources may initiate criminal activities, especially in a restricted environment such as East Albany. Income constraint could lead to an irrational behavior that could lead to criminal activities. Severe income constraint is capable of inducing severe irrational behavior expressed in severe criminality. With a severe income constraint, benefits from crimes could be rationalized as if the return to criminality is from an economic market. A critical income constraint could lead to a behavior that maximizes the net benefit from crimes by weighing the benefit against costs from criminal events. Net benefits could therefore be maximized according to marginal analysis principle. The more liberal the returns from crimes, the more likely people will self-select criminal activities. Therefore, crimes would be produced up to the optimal level where marginal benefit from criminal activities is at par with marginal cost from crimes.

Time is scarce and a criminal may want to maximize benefits from crimes just as non-criminals maximize earnings from the labor and bonds markets. Searching for economic opportunities beyond a remote environment, such as Dougherty County, could be very time-consuming. The time constraint could compel criminals to allocate more time to crimes than to other activities whereby crimes seem to be rewarding. Immediate gratification and hedonic consumption could compel time intensiveness in criminal activities. A short time orientation in conspicuous consumption could most likely lead to a desperate criminal behavior. Dualistic and restricted environment is most likely to have hedonic consumption and criminal activities. City vices could explain why some White residents in the city of Albany are moving to the suburbs.

Given resource scarcity, criminals tend to make economic decisions by comparing expected benefits from crime to the expected costs from crimes. They could estimate the expected benefits from crimes by assigning probability $(P c)$ to benefits from crimes when not caught and probability $(P c c)$ to benefits from being caught in a crime, and probability $(P p)$ of punishment from crimes. This criminal assumption is stated by the following equation:

Expected Benefits from crimes $=P c($ Benefits from crimes $)+P c c($ Benefits associated from being caught $)-P p($ Punishment from crimes)

Probabilities of Pc and Pcc equal unity while probability (Pp) could take any value from zero to unity depending on its evaluation. Zero probability assigned to punishment would mean that there is no expected punishment for crimes. The law tends to beef up the probability attached to punishment. A unit probability on punishment would signal a minimum penalty from crimes. Why do people commit crimes even if they are aware that punishment could be punitive? With resource scarcity and poverty, criminals tend to overestimate the probability of not being caught and to underestimate the probability associated with punishment. Even with the state of Georgia's mandatory long jail sentences for repeat offenses, some criminals still repeat crimes. By underestimating the probability associated with punishment, criminals tend to see punishment subjectively. Lowering this probability expects punishment to be lenient. Given poverty and a constant probability of not being caught in crimes, if the benefits are increasing, the expected benefits from crimes will increase. Crimes will become more self-selected which means that this compelling situation will tend to create more incentive to engage in 
criminal activities. On the other hand, a decreasing benefit at a constant probability of not being caught will decrease the expected return from crimes.

If the benefits associated from being caught in crimes is on the rise, then the expected benefits from crimes will increase. The criminals who consider confinement facility as a home of last resort will want to commit crimes if the benefits from being caught are rising at the associated constant probability. Repeat offenders could take advantage of increasing benefits from being caught at this constant probability to perpetuate criminal activities. Some people could voluntarily commit crimes with increasing benefits from being caught. Some people could become career criminals where the incarcerating institutions seem to become more and more comfortable. With a decreasing reward from being caught in crime, the expected benefits from crimes would decrease. Punishment serves as crime deterrents. From the legal perspective, if the probability associated to administering punishments leans toward unity, there is a high likelihood for the expected cost of crime to exceed the combined expected benefits from being caught and not caught in criminal activities. In this scenario, a would-be criminal would be expecting costs that could be higher than the expected benefit.

\section{DATA AND RESEARCH METHODOLOGY}

The time series data on annual variables that can explain the crimes and poverty in the county cover the period from 1990 to 2008. It is unfortunate that most of these series were discontinued after 2008. If available, this study will highlight the current estimates of the variables. The crimes, unemployment rate, and the average weekly wages variables (proxies for poverty) are respectively obtained from Georgia Bureau of Investigation and Georgia Department of Labor. The unemployment rate could provide clues on the effect of both discrimination and variation of the economy on poverty and purchasing power disparity (another proxy for poverty). We retrieved the purchasing power variables for constructing the purchasing power disparity from The Multicultural Economy, Selig Center for Economic Growth in Terry College of The University of Georgia. This study uses the average rate of "AAA" Industrial Bonds only ${ }^{16}$ to assess employment substitutability between Black workers and capital. The Website of Georgia Department of Correction provides the incarceration series. Dougherty County Public School System provides the graduation and dropout rates variables that could explain self-selection into market or criminal activities. The county's descriptive statistics of the major series - real weekly wage (Rww), incarceration ratio, (Incar Dispa), and unemployment rate (Unemp Rate), and measures of other variables are presented in Table 1.

Table 1: Summary Statistics

\begin{tabular}{|l|l|l|c|}
\hline \multicolumn{1}{|c|}{ Variable Name } & \multicolumn{1}{c|}{ Mean } & Standard Deviation & Interquatile Range \\
\hline Real Weekly Wage & 403.93 & 11.38 & 24.40 \\
\hline Black Purchase Power (thousands of dollars) & 734786.1 & $210,133.4$ & $397,576.5$ \\
\hline White Purchase Power (thousands of dollars) & $1,071,324$ & $103,246.7$ & $187,915.8$ \\
\hline Purchasing Power Disparity & 0.48 & 0.065 & 0.12 \\
\hline High School Graduation Rate: 2002-2009 & 59.69 & 5.28 & \\
\hline High School Dropout Rate: 2002-2009 & 5.98 & 1.5 & 2941.5 \\
\hline Crimes & 7406 & 1600.42 & $2.09 \%$ \\
\hline Unemployment rate & $6.65 \%$ & $1.23 \%$ & \\
\hline Poverty Rate: 2010 & $22.3 \%$ & & \\
\hline Unwed Mothers: 1990-2006 & 946.94 & 34.18 & \\
\hline Teenage Pregnancies 1994-2006 & 407.53 & 51.35 & 0.12 \\
\hline Purchasing Power Disparity & 0.69 & 32.065 & 36.25 \\
\hline Incarcerated Blacks & 395 & 8.34 & 13.75 \\
\hline Incarcerated Whites & 74 & 0.71 & 1.18 \\
\hline Incarceration Ratio & 5.46 & & \\
\hline Highest No. of Observations: 19 & & & \\
\hline
\end{tabular}

The real average weekly wage seems to be very low in the face of a very high unemployment rate that characterizes the county. Having a low wage generally results from a declining demand for labor and, specifically, from having non-White residents highly distributed in low paying jobs, or from paying low wages to members of the non-White residents on comparable jobs that pay higher wages to the White residents.

${ }^{16}$ The variable is available from: Http://www.federalreserve.gov/releases/H15/data/M 
White population of Dougherty County commands a disproportional part of the overall purchasing power relative to the $37.34 \%$ of this group's population in the county. An estimate of 0.69 of the purchasing power disparity implies that 69 cents is earned by an average Black man for every dollar earned by an average White man. This disproportional purchasing power may reflect White superior suburban education and favorable wealth distribution by non-market factors of inheritance, discrimination and segregation, restricted and dualistic environment, and lack of entrepreneurial foresight from among the non-White residents. Most members of the nonWhite groups earn incomes that constitute their purchasing powers from mostly the labor market. A graduation rate of $59.69 \%$ is very low and unacceptable. Recall that this rate may not reflect an acceptable quality of the graduates. Human capital accumulation will be adversely affected with a low qualitative education. A low quality education will adversely affect the graduates' ability to apply to high-level jobs and would also diminish entrepreneurial responsibility.

The level of crimes is very high relative to the population of the county. Given the county's 2008 population ${ }^{17}$ of 95,754 and the number of all crimes $(7,131)$, the associated per capital crime is 0.074 . The estimate implies that each person in the county shares 0.074 of the county's crimes. With this estimate, businesses and professionals may have doubt relocating to the county. Recall that the White migration from the central city of Albany is partly in response to the city vices. A continuous migration from this resource-based group would magnify the area's economic stagnation. Increasing crimes leads to life insecurity and business uncertainty. These adversities would minimize an optimal planning that is necessary to have harmonized communities within the county.

The respective incarceration rates of African Americans and White people of 0.005 and 0.0009 in 2010 will highlight an extensive incarceration from the race/ethnic group that experiences the most severe economic deprivation (poverty). Here is more proof that poverty is positively related with crimes. Statistically speaking, the rates imply that 50 persons out of 10,000 African Americans and 9 persons out 10,000 White people are incarcerated. A high unemployment rate characterizes the county. These misery indexes show market functionality leads to a poverty rate of $25.3 \%$ in the county (Georgia County Guide, 2010). Given these rates, a resolution of poverty and crimes in the county may require a robust amount of exogenous investments to bring the unemployment rate closer to its natural rate.

\section{THEORETICAL AND EMPIRICAL EQUATIONS AND RESULTS}

The real average wage rate is assumed to be derived from production functions. This wage would fluctuate due to the change in the proxies of poverty. Therefore, the real average wage rate in the county can be stated as a linear function of the proxies of poverty (low purchasing power) as:

Wage rate $=\mathrm{f}$ (graduation rate, unemployment rate, incarceration, teenage pregnancies and unwed mothers $)$

With other things being constant, an increasing graduation rate will build up the human capital that will have a positive impact on the marginal product of labor and therefore on the wage rate. An increasing unemployment rate suggests a declining labor demand that suppresses the average wage rate. The supply of labor would decrease by incarceration and would increase with the release of the inmates. Since both the incarcerated and felons are most likely to earn less than the value of their marginal products of labor, their earnings would lead to a decrease of the average wage rate. Both teenage pregnancies and unwed mothers are most likely to have limited education that would translate to lower earnings thus lower the average wage rate.

In Dougherty County, the proxy of poverty (a low or stagnant wage rate) is also characterized by exogenous, non-market situations of the dualistic environment, discrimination and segregation, the remoteness of the county, and a highly limited Black entrepreneurship. Exodus of White and Black middle class out of the county has magnified the level of poverty that explains crimes. The statement here will lead to stating crimes as a linear function of the proxy for poverty (real wage rate):

\footnotetext{
${ }^{17}$ The county's population estimate is retrieved from 2010 Georgia County Guide, Center for Agriculture and Economic Development, UGA, Athens.
} 
Crimes $=\mathrm{f}($ wage rate $)$

An increasing average weekly wage rate will reflect an increasing demand for labor. A declining average or stagnant wage rate (poverty) could reflect a declining demand for labor which could motivate crimes. A negative relationship is therefore expected between crimes and the average weekly wage rate. If labor is being qualified for jobs and for entrepreneurship, the average weekly wage rate would reflect an increasing value of marginal product of labor. Increasing average weekly wage rate and employment will most likely diminish criminality. The level of crimes can also be stated as a function of the factors that cause the average wage rate to be stochastic as:

Crimes $=\mathrm{f}($ graduation rate, unemployment rate, incarceration, teenage pregnancy $)$

An increasing employment - a substitute for crimes - would most likely decrease the non-violent crimes. The major descriptive series constructed from the relative values ${ }^{18}$ for the real average weekly wage rate, unemployment rate, crimes, incarceration, and purchasing power are shown in Figure 1.

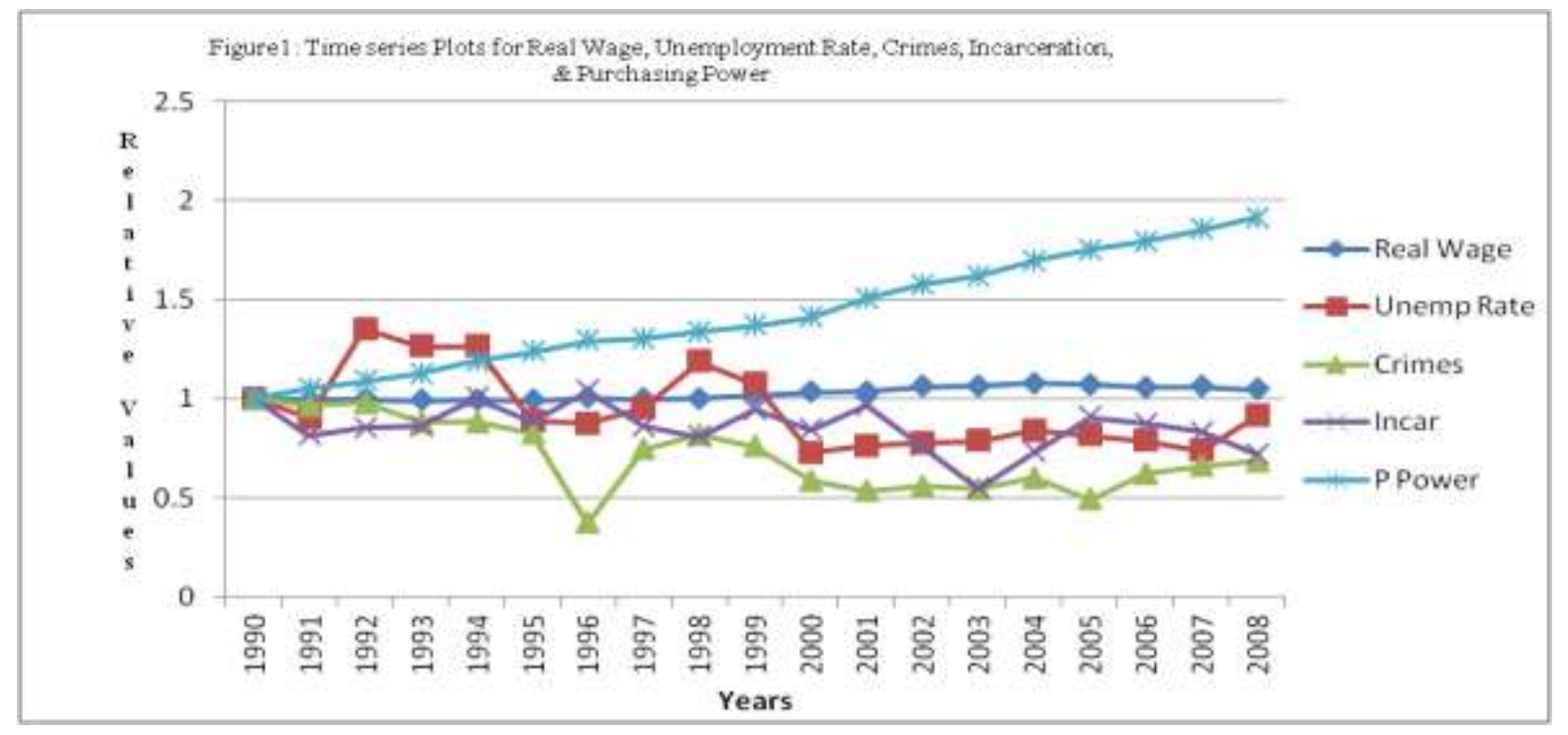

Figure 1 depicts stochastic series of unemployment rate (unemp rate), crimes, incarceration (incar), and purchasing power (P power) variables, as well as a stagnant series of the real average weekly wage rate and an increasing series of the purchasing power. The stochastic incarceration series could reflect the state of Georgia's mandatory sentencing for repeat offenders, equity, and duration of trial and convictions in the justice system. Generally, the trend of the crime factor seems to reflect the pattern of the unemployment rate. An increasing purchasing power contrasts the stagnant trend of the wage rate. This contrast would imply that the purchasing power is increasing from non-labor market activities.

\section{Empirical Analysis}

Define a ratio of the change in crimes due to a change from each of the respective crimes' deterministic variables - graduation rate, unemployment rate, incarceration, as: $\dot{X}=\frac{\Delta Y}{\Delta X}$. The sign and magnitude of the respective ratio provides the relationship between a particular variable and crimes. For example, a positive ratio of mean of crimes and mean of value of a particular variable would imply that crimes would increase/decrease if the particular variable increases/decreases. The ratio of means of crime, graduation rate, unemployment rate, and incarceration are $-83.26,4710$, and 27.02 , respectively. The ratio $(-83.26)$ of crimes and graduation (proxy

${ }^{18}$ Define a relative value as Xt/X1990 where Xt is the observation of period t and X1990 is the base year's observation. 
determinant of wage rate) implies that if the wage rate goes down by a unit percentage point, then crimes will go up by 83.26 percentage points with other things remaining constant. A declining wage rate could reflect a declining demand for labor due to exits of the big establishments. The relationship between crimes and any other particular variable can therefore be interpreted given the sign and the magnitude of the respective ratio.

\section{POLICY IMPLICATIONS AND DIRECTION FOR FUTURE RESEARCH}

Dougherty County is characterized by high crime, poverty, and unemployment rates. This paper has successfully linked crimes to poverty that is mostly explained by educational factors, unemployment rate, and incarceration. A solution to the poverty that would have impact on diminishing crimes has to start with a rising standard of quality education. The current public school system's graduation rate is unacceptable. The Dougherty County School System has to get to the root that causes this and correct the failing public schools. Educated citizenry would increase productivity that would be responsible for boasting the average weekly wage rate. The propensity to commit crimes could diminish with an exhibition of market rational behavior and with an increasing return from the labor market where workers are paid by productivity. Effort must be geared toward identifying and reinforcing the market capability of each student.

Polices would adequately reflect production-related incentives for attracting new businesses and for those that left the county to come back. Since the exit of some of the major establishments has exacerbated the unemployment rate crisis in the county, it stands to reason that both labor and capital intensive establishments have to be encouraged with the appropriate production incentives.

Felons need proper general education, adequate vocational trainings, and market orientations before being released to society. A general education will enable felons to recognize the basic norms of the society, the impact of resource scarcity, and the associated costs of being a felon. The felons have to understand that talents are developed in schools and market arenas, not in incarceration. From a market perspective, they have to understand that the additional cost of engaging in additional crime could be substantially greater than any additional benefit from the additional crime. In conclusion, it is apparently clear that there is a positive relationship between crimes and poverty. This paper encourages quality education, invitation of businesses, and exposure of criminals to proper and adequate trainings and to market orientations to diminish crimes. Supporting these initiatives will maximize productivity and the return from the labor market where most people earn their purchasing powers.

Both the remoteness of the county and the associated dualistic and segregated environments have been long standing exogenous adversities. The economic market seems unable to resolve the adversities. Future research will have to address some kind of exogenous factors for resolving the adversities. Market may not resolve the economic adversities in the county. Therefore, desperate discretionary economic policy and action, as well as harmonized planning, need to be applied to the economy of Dougherty County. An adequate investment intervention is expected in the economy to resolve both poverty and crimes.

\section{AUTHOR INFORMATION}

Dr. Amaechi N. Nwaokoro is an Associate Professor of Economics at Albany State University in Albany, Georgia. He earned a doctorate in economics from University of Oklahoma, a Masters of Business Administration from Oklahoma City University, and a bachelor degree in Business \& Economics from Northwestern Oklahoma State University. Dr. Nwaokoro has published more than half- a- dozen refereed journal articles and some conference proceedings. He is currently researching and writing manuscripts for publication. He has over ten years of continuous teaching experience at both undergraduate and graduate levels of economic education. As a member of Southwestern Social Science Association, he reviews articles for Southwestern Journal of Economics, an affiliate of the association. He has made various professional presentations during the meetings of this association. Economics is his passion and he also enjoys traveling. He enjoys doing charity work. This is another call that also requires his time here on earth. For more details about his background, research interests, publications, and work experience, you can request his full resume. Dr. Nwaokoro can be reached at 229-430-4723 or e-mail: Amaechi.nwaokoro@asurams.edu (Corresponding author) 
Dr. Clifford L. Marshall is an Associate Professor of Accounting in the College of Business at Albany State University, Albany, Georgia. Professor Marshall has taught at Albany State University for four years. Dr. Marshall's previous teaching assignments were at Bishop College, Florida A\&M University, Tuskegee University, Bethune Cookman University, University of Arkansas at Pine Bluff, and a volunteer assistant at Lane College. Dr. Marshall's industrial experience comes from Eastman Kodak, IBM, Sohio Corporation, Mobil Oil Corporation, Society Bank and Aluminum Company of America. Professor Marshall's research topics in previous years include "The Black Experience at Big Eight Public Accounting Firms," "Miami Perils, The Tip of the Iceberg," "Investment Strategies for the U.S. Businesses in Zimbabwe," "Inflation Accounting" and "Alternative Energy methods-Cellulosic Ethanol, Wind, and Solar Power." Dr. Marshall is married to Lea Denson Marshall and has a grandson and granddaughter. His interest includes reading, traveling, Bridge and Bid-Whiz card playing, and working with accounting students. Dr. Clifford L. Marshall can be reached at 229-430-4778 or e-mail: clifford.marshall@asurams.edu

Shiwam Mittal is a third-year undergraduate at Birla Institute of Technology and Sciences in Pilani, India and is currently jointly pursuing Masters of Sciences (Hons) in Economics and Bachelor of Engineering (Hons) in Electrical and Electronics Engineering. He will be graduating in 2015. He is quite passionate about various fields of economics, and his primary interests include microeconomics, macroeconomics, game theory and programming. He can be reached at email: shiwammittal@gmail.com

\section{REFERENCES}

1. Adams-Cooper, V., 2010. “Addressing the Roots of Black Poverty in the United States: A Proposed Dual Macro-Micro, Niche-Market Network Systems Approach [White Paper]”. Albany, GA: VAAC Consulting Inc.

2. Bagi, Sukhwinder, 2008. "An Analysis of Inequality, Human Development, and Economic Growth”. Southwestern Journal of Economics, v. x, no. 2, 69-80.

3. Baldwin, Marjorie L. and William G. Johnson, 1996. "The Employment Effects of Wage Discrimination Against Black Men”. Industrial \& labor Relations Review, 302-316.

4. Ballard, Bill 2008. "A Keynes/Post Keynesian Analysis of the Wealth". Presented at 2008 Southwestern Economics Association, Denver, Colorado, Working Paper.

5. Becker, G.S. 1968. "Crime and Punishment: An Economic Approach" Journal of Political Economy, 76, no. 2, 169-217.

6. Browne, Irene, 1997. "Explaining the Black-White Gap in Labor Force Participation Among Women Heading Households". American Sociological Review, 236-252.

7. Chiu, Henry W., Paul Madden 1998. "Burglary and Income Inequality” Journal of Public Economics, 123141.

8. Comanor, William, and S. Llad Phillips 2002. "The Impact of Income and Family Structure on Delinquency", Journal of Applied Economics, v. 5, no. 2, 209-24.

9. D'Amico, Ronald and Nan L. Maxwell, 1994. "The Impact of Post-School Joblessness on Male Black Wage Differentials". Industrial Relations, 184-205.

10. Dagg, P.K., 1991. "The Psychological Sequelae of Therapeutic Abortion—Denied and Completed" American Journal of Psychiatry, 578-585.

11. Davis Alison F. and Simona Balazs, 2011. "Is Going Local a Sustainable Strategy for Communities". Southwestern Economic Association, Working Paper, 1-2.

12. Donohue III, John, Steven Levitt, 2001. "Legalized Abortion and Crime”. Quarterly Journal of Economics, v.116, no. 2: 379-420.

13. Donohue III, John, Steven Levitt, 2004. "Further Evidence that Legalized Abortion Lowered Crime". The Journal of Human Resources, 29-49.

14. Dougherty County School System. 2002-2009 DCSS Graduation \& Dropout Rates. Dougherty County School System. Albany, Georgia.

15. Ehrlich, Isaac 1973. "Participation in Illegitimate Activities: A Theoretical and Empirical Investigation". Journal of Political Economy, v. 81, no. 3, 521-565.

16. Farr, Jessica L. and Sibyl S. Slade. 2008. "Albany, Georgia: the East Albany Neighborhood”. Albany Georgia. 
17. Gardner, Jennifer M. and Diane E. Hern. 1992. "Working and Poor in 1990". Monthly Labor Review, 2028.

18. Georgia Bureau of Investigation 2010. Crime Statistics. Georgia Bureau of Investigation.

19. Georgia County Guide, 2010. Center for Agribusiness and Economic Development, UGA, Athens, Georgia.

20. Georgia Department of Corrections 2010. Reports: Annual Statistics. Georgia Department of Corrections.

21. Georgia Department of Labor 1990-2008, 2010. Workforce Professionals: Historical Data. Georgia Department of Labor.

22. Gittleman, Maury and Edward N. Wolff, 2004. "Racial Differences in Patterns of Wealth Accumulation". The Journal of Human Resources, v. 39, no 1, 193-227.

23. Glaeser , Edward L., Bruce Sacerdote, 1999. "Why Is There More Crime in Cities?” Journal of Political Economy, v.107, no. 6, 225-258.

24. Hartung Gabriel, Samuel Pessoa 2007. “Populacao Probreza Desigualdade” Brazilian Journal of Population Studies.

25. Hoynes, Hilary W. et al., 2006. "Poverty in America: Trends and Explanations". Journal of Economic Perspectives, 47-68.

26. Kelly, Morgan, 2000. "Inequality and Crime". The Review of Economics and Statistics, v. 82, no. 4, 530539.

27. Owen, James and John Martinez, 2008. "Income Inequality Trend in Texas". Working Paper, Midwestern State University.

28. Nwaokoro, Amaechi, 2012. "Sources, Stigmatization, and Alleviation of Poverty in Albany/Dougherty, Georgia", The Journal of Applied Business Research, v. 28, no. 2, 155-170.

29. Peeples, Faith, and Rolf Loeber, 1994. Do Individual Factors and Neighborhood Explain Ethnic Differences in Juvenile Delinquency? ”Journal of Quantitative Criminology, v. 10, no. 2, 141-157.

30. Schmitt, John, 2004. "The Rise in Job Displacement, 1991-2004". Challenge, 46-68.

31. Smith, Ralph E. and Bruce Vavrichek 1987. "The Minimum Wage: It's Relation to Incomes and Poverty". Monthly Labor Review, 24-30.

32. Theodos, Brett and Robert Bednarzik, 2006. "Earnings Mobility and low-wage workers in the United States". Monthly Labor Review, 34-47.

33. The University of Georgia, Terry College of Business, Selig Center for Economic Growth, 2009. Georgia Economic Outlook. Terry College of Business, Selig Center for Economic Growth.

34. U.S. Bureau of the Census, 2000. "Income and Poverty in Dougherty County". U.S. Bureau of the Census. 


\section{NOTES}

